\title{
Geographic Trends for United States Allopathic Seniors Participating in the Residency Match: a Descriptive Analysis
}

\author{
Claire N. Shappell, $M D^{7}$, Jeanne M. Farnan, MD, MHPE' ${ }^{2}$, John F. McConville, MD², and \\ Shannon K. Martin, MD, MS ${ }^{2}$
}

'Brigham and Women's Hospital, Boston, MA, USA; ²Department of Medicine, Pritzker School of Medicine, University of Chicago, Chicago, IL, USA.

$J$ Gen Intern Med 34(2):179-81

DOI: $10.1007 / \mathrm{s} 11606-018-4686-1$

(c) Society of General Internal Medicine 2018

\section{INTRODUCTION}

Geography is consistently cited as an important factor in residency applicant decision-making, ${ }^{1}$ but little is known about where students match into residency based on medical school of origin. We aimed to characterize geographic trends for US graduating allopathic seniors participating in the National Resident Matching Program (NRMP).

\section{METHODS}

De-identified NRMP data were obtained for all US graduating allopathic seniors participating in the 2011-2015 Main Residency Match $®$ in all specialties. Data were grouped into four geographic regions and nine divisions based upon applicants' medical schools using US census definitions (Fig. 1). "Home" region/division was defined as applicants matching into the same geographic region and division where their medical school was located. Chi-square and logistic regression analyses were performed using Stata, controlling for year and using East North Central (ENC) division as the referent group. This study was exempted by the University of Chicago IRB (IRB126-0721).

\section{RESULTS}

Of 84,810 US seniors participating in the Match, 80,707 matched (Table 1). Sixty-three percent of applicants matched at programs within their home regions $(n=$ $50,809$ ), and $51 \%$ within home divisions ( $n=40,973)$, with variation between regions and divisions (Fig. 1). These proportions did not differ significantly from 2011 to 2015 (region $\chi 2=5.6, p=0.23$; division $\chi 2=7.9, p=0.09$ ). The odds of an applicant matching within their home division were highest in the Pacific division $(\mathrm{OR}=1.79,95 \% \mathrm{CI}$ [1.69-1.90], $p<0.001)$, and lowest in the Mountain (OR = $0.64,95 \%$ CI [0.58-0.69], $p<0.001)$ division, compared to ENC. Programs had highest odds of matching residents remaining in home divisions in the West South Central

Published online October 1, 2018 division ( $\mathrm{OR}=1.30,95 \% \mathrm{CI}[1.23-1.38], p<0.001)$, and lowest in the Mountain division $(\mathrm{OR}=0.22,95 \% \mathrm{CI}[0.21$ $0.24], p<0.001)$, compared to ENC.

\section{DISCUSSION}

This study uses national data to describe geographic trends in the residency Match. Our results objectively demonstrate that residency applicants, on average, have matched in relatively close geographic proximity to their medical schools in recent years, though there is significant variability between regions and divisions. From the program perspective, there is much more inter-divisional variation in the proportion of matched residents recruited from that division. Low percentages of matched residents from the program division, such as seen in Mountain (26\%) and New England (32\%) divisions, may indicate desirability of the divisions to outside applicants, or may reflect the greater number of matched residents than graduating students in those divisions, making broader recruitment necessary. Perhaps surprisingly, we found that the proportion of students remaining in their home division has not changed significantly over the 5 years we examined, despite anecdotal perceptions of increasing regionalization in the recruitment process.

Our results confirm a longstanding view that students tend to match locally and strengthen prior work in this area. Previous studies have been narrowly focused, primarily in surgical subspecialties which may not be generalizable, and suffer from incomplete data that is potentially subject to bias. ${ }^{2-4}$ To our knowledge, this is the first study to use objective, nationwide data to examine this question.

Additionally, this work has potential to inform the growing body of literature about application inflation in the residency Match, a rising issue in medical education ${ }^{5}$. While our data provides a broad view of geographic trends, further study may help applicants better understand the geographic matching patterns of programs of interest within certain areas, thus allowing applicants to more carefully consider their application strategy. Likewise, residency programs trying to conserve resources may use these data and future work to understand potential geographic factors when making decisions to offer limited number of interviews. However, while this has the 


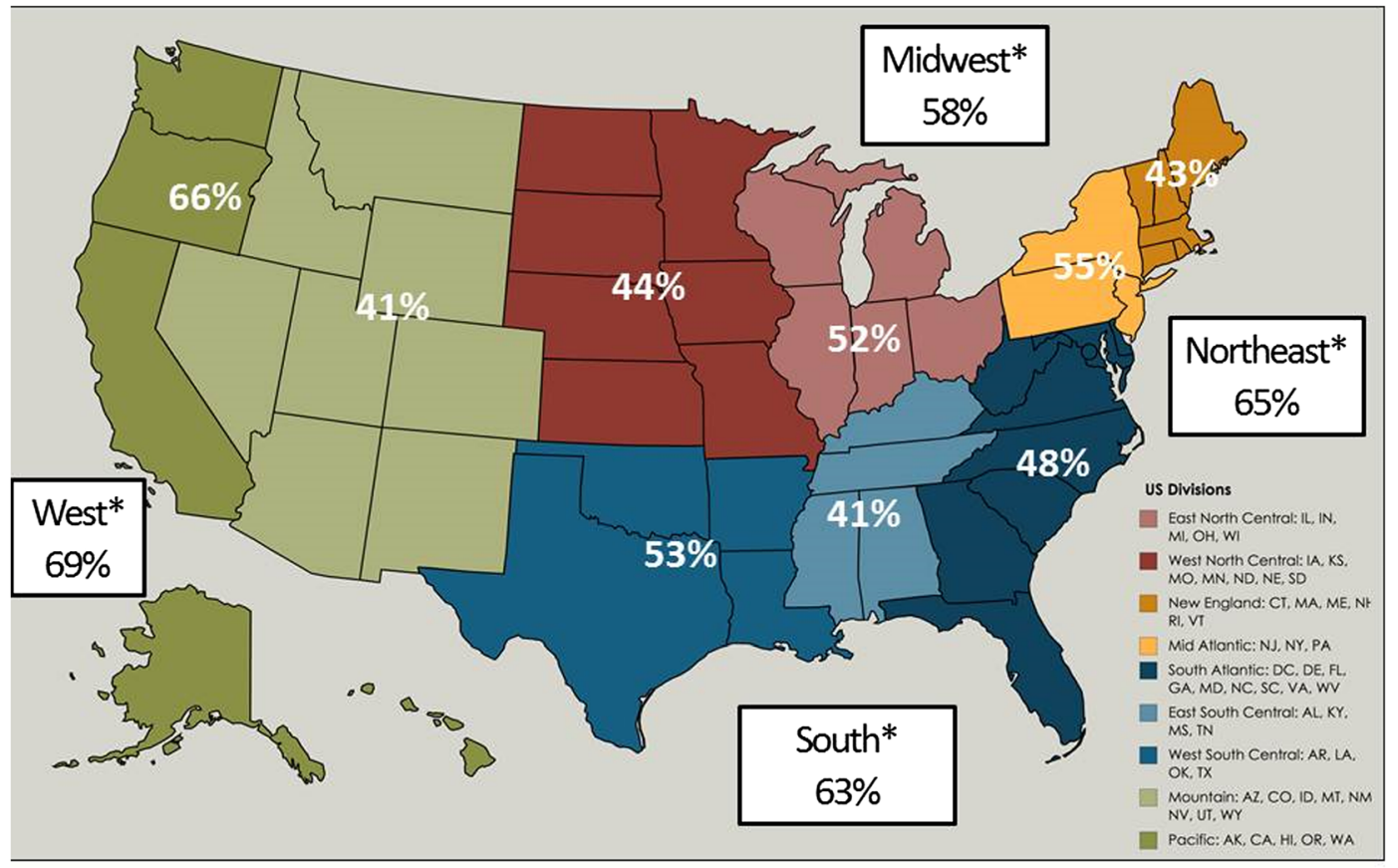

*US Regions = Midwest, Northeast, South, West

Figure 1 Percentage of applicants who matched in their home geographic region and division (i.e., the same geographic region and division where their medical school was located).

Table 1 Geographic Distribution of Matched Allopathic Applicants and Residents in All Specialties 2011-2015

\begin{tabular}{|c|c|c|c|c|c|c|c|c|c|c|}
\hline Region & $\begin{array}{l}\text { Total } \\
\text { applicants } \\
\text { originating } \\
\text { from } \\
\text { region, } n\end{array}$ & $\begin{array}{l}\text { Total } \\
\text { matched } \\
\text { applicants } \\
\text { originating } \\
\text { from } \\
\text { region, } n \\
(\%)\end{array}$ & $\begin{array}{l}\text { Total } \\
\text { applicants } \\
\text { matching } \\
\text { into } \\
\text { program } \\
\text { region, } n\end{array}$ & $\begin{array}{l}\text { Total } \\
\text { matched } \\
\text { residents } \\
\text { remaining } \\
\text { in home } \\
\text { region }^{\mathrm{a}}, n\end{array}$ & $\begin{array}{l}\text { Proportion } \\
\text { of } \\
\text { applicants } \\
\text { matching } \\
\text { into their } \\
\text { home } \\
\text { region, \% }\end{array}$ & $\begin{array}{l}\mathrm{OR}^{\mathrm{b}} \text { of } \\
\text { applicants } \\
\text { matching } \\
\text { into home } \\
\text { region } \\
(95 \% \mathrm{CI})\end{array}$ & $p$ & $\begin{array}{l}\text { Proportion } \\
\text { of matched } \\
\text { residents in } \\
\text { programs } \\
\text { remaining } \\
\text { in home } \\
\text { region, \% }\end{array}$ & $\begin{array}{l}\text { OR of } \\
\text { program } \\
\text { matching } \\
\text { a resident } \\
\text { from } \\
\text { home } \\
\text { region } \\
(95 \% \mathrm{CI})\end{array}$ & $p$ \\
\hline Midwest & 23,153 & $21,944(95)$ & 18,496 & 12,732 & 58 & REF & & 69 & REF & \\
\hline Northeast & 21,456 & 20,731 (97) & 21,558 & 13,497 & 65 & $\begin{array}{l}1.35(1.30, \\
1.40)\end{array}$ & $\begin{array}{l}< \\
0.001\end{array}$ & 63 & $\begin{array}{l}0.76 \\
(0.73- \\
0.79)\end{array}$ & $\begin{array}{l}< \\
0.001\end{array}$ \\
\hline South & 30,493 & 28,725 (94) & 24,750 & 18,185 & 63 & $\begin{array}{l}1.25(1.20, \\
1.29)\end{array}$ & $\begin{array}{l}< \\
0.001\end{array}$ & 73 & $\begin{array}{l}1.25 \\
(1.20- \\
1.31)\end{array}$ & $\begin{array}{l}< \\
0.001\end{array}$ \\
\hline West & 9708 & 9307 (96) & 15,903 & 6395 & 69 & $\begin{array}{l}1.59(1.51, \\
1.67)\end{array}$ & $\begin{array}{l}< \\
0.001\end{array}$ & 40 & $\begin{array}{l}0.30 \\
(0.29- \\
0.32)\end{array}$ & $\begin{array}{l}< \\
0.001\end{array}$ \\
\hline Total & 84,810 & 80,707 (95) & 80,707 & 50,809 & 63 & & & 63 & & \\
\hline Division & $\begin{array}{l}\text { Total } \\
\text { applicants } \\
\text { originating } \\
\text { from } \\
\text { division, } n\end{array}$ & $\begin{array}{l}\text { Total } \\
\text { matched } \\
\text { applicants } \\
\text { originating } \\
\text { from } \\
\text { division, } n \\
(\%)\end{array}$ & $\begin{array}{l}\text { Total } \\
\text { applicants } \\
\text { matching } \\
\text { into } \\
\text { program } \\
\text { division, } n\end{array}$ & $\begin{array}{l}\text { Total } \\
\text { matched } \\
\text { residents } \\
\text { remaining } \\
\text { in home } \\
\text { division, } n\end{array}$ & $\begin{array}{l}\text { Proportion } \\
\text { of } \\
\text { applicants } \\
\text { matching } \\
\text { into home } \\
\text { division, \% }\end{array}$ & $\begin{array}{l}\text { OR of } \\
\text { applicants } \\
\text { matching } \\
\text { into home } \\
\text { division } \\
(95 \% \mathrm{CI})\end{array}$ & $p$ & $\begin{array}{l}\text { Proportion } \\
\text { of matched } \\
\text { residents in } \\
\text { program } \\
\text { remaining } \\
\text { in home } \\
\text { division, \% }\end{array}$ & $\begin{array}{l}\text { OR of } \\
\text { program } \\
\text { matching } \\
\text { a resident } \\
\text { from } \\
\text { home } \\
\text { division } \\
(95 \% \mathrm{CI})\end{array}$ & $p$ \\
\hline $\begin{array}{l}\text { Midwest } \\
\text { East } \\
\text { North } \\
\text { Central }\end{array}$ & 16,186 & $15,320(95)$ & 13,040 & 7907 & 52 & REF & & 61 & REF & \\
\hline $\begin{array}{l}\text { West } \\
\text { North } \\
\text { Central } \\
\text { Northeast }\end{array}$ & 6967 & $6624(95)$ & 5456 & 2889 & 44 & $\begin{array}{l}0.73(0.68- \\
0.77)\end{array}$ & $\begin{array}{l}< \\
0.001\end{array}$ & 53 & $\begin{array}{l}0.73 \\
(0.69 \\
0.78)\end{array}$ & $\begin{array}{l}< \\
0.001\end{array}$ \\
\hline
\end{tabular}


Table 1. (continued)

\begin{tabular}{|c|c|c|c|c|c|c|c|c|c|c|}
\hline $\begin{array}{l}\text { New } \\
\text { England }\end{array}$ & 5340 & $5186(97)$ & 7038 & 2245 & 43 & $\begin{array}{l}0.72(0.67- \\
0.76)\end{array}$ & $\begin{array}{l}< \\
0.001\end{array}$ & 32 & $\begin{array}{l}0.30 \\
(0.29 \\
0.32)\end{array}$ & $\begin{array}{l}< \\
0.001\end{array}$ \\
\hline $\begin{array}{l}\text { Mid- } \\
\text { Atlantic }\end{array}$ & 16,116 & $15,545(96)$ & 14,520 & 8513 & 55 & $\begin{array}{l}1.13(1.09- \\
1.19)\end{array}$ & $\begin{array}{l}< \\
0.001\end{array}$ & 59 & $\begin{array}{l}0.92 \\
(0.88- \\
0.97)\end{array}$ & 0.001 \\
\hline $\begin{array}{l}\text { South } \\
\text { South } \\
\text { Atlantic }\end{array}$ & 15,096 & $14,291(95)$ & 13,049 & 6861 & 48 & $\begin{array}{l}0.87(0.83- \\
0.91)\end{array}$ & $<0.001$ & 53 & $\begin{array}{l}0.72 \\
(0.69 \\
0.76)\end{array}$ & $\begin{array}{l}< \\
0.001\end{array}$ \\
\hline $\begin{array}{l}\text { East } \\
\text { South } \\
\text { Central }\end{array}$ & 5004 & 4691 (94) & 4011 & 1927 & 41 & $\begin{array}{l}0.65(0.61- \\
0.7)\end{array}$ & $\begin{array}{l}< \\
0.001\end{array}$ & 48 & $\begin{array}{l}0.60 \\
(0.56- \\
0.64)\end{array}$ & $\begin{array}{l}< \\
0.001\end{array}$ \\
\hline $\begin{array}{l}\text { West } \\
\text { South } \\
\text { Central } \\
\text { West }\end{array}$ & 10,393 & 9743 (94) & 7690 & 5134 & 53 & $\begin{array}{l}1.05(0.99- \\
1.10)\end{array}$ & 0.093 & 67 & $\begin{array}{l}1.30 \\
(1.23- \\
1.38)\end{array}$ & $\begin{array}{l}< \\
0.001\end{array}$ \\
\hline Mountain & 2591 & $2435(94)$ & 3849 & 985 & 41 & $\begin{array}{l}0.64(0.58- \\
0.69)\end{array}$ & $<0.001$ & 26 & $\begin{array}{l}0.22 \\
(0.21- \\
0.24)\end{array}$ & $\begin{array}{l}< \\
0.001\end{array}$ \\
\hline Pacific & 7117 & $6872(97)$ & 12,054 & 4512 & 66 & $\begin{array}{l}1.79(1.69- \\
1.90)\end{array}$ & $<0.001$ & 37 & $\begin{array}{l}0.39 \\
(0.37- \\
0.41)\end{array}$ & $\begin{array}{l}< \\
0.001\end{array}$ \\
\hline Total & 84,810 & 80,707 (95) & 80,707 & 40,973 & 51 & & & 51 & & \\
\hline
\end{tabular}

"Home" region or division defined as region or division where applicant's medical school is located

${ }^{b} \mathrm{OR}$, odds ratio. Logistic regression model adjusted for year

potential to improve recruitment efficiency and reduce costs, it may disadvantage students wishing to move to a new geographic area.

While the data supporting our findings are robust, our study has important limitations. Data available from the NRMP were stripped of potential identifiers beyond year and geography, and therefore groups encompassed an amalgam of heterogeneous institutions. We also lack data on applicants' other geographic ties, such as locations of family or spouses, which are likely to have an outsized effect on application decisions. Further, applicant competitiveness, as gauged by USMLE scores, grades, and honor society membership, were not available. Regardless, this study is the first to describe geographic trends in the Match using nationally available data from the NRMP and provides foundational evidence in this area.

Acknowledgements: Contributors: We would like to thank the National Resident Matching Program for collecting and providing the data utilized in the study, as well as for their contribution to the manuscript.

Prior presentations: Preliminary results of this work were presented as a poster presentation at the Department of Medicine Resident Research Day at the University of Chicago in March 2017, as a poster presentation at the Midwest Society of General Internal Medicine conference in Chicago, Illinois in September, 2017, and as an oral plenary presentation at the University of Chicago Medical Education Day in November 2017.

Corresponding Author: Shannon K. Martin, MD, MS; Department of Medicine, Pritzker School of MedicineUniversity of Chicago, Chicago, IL, USA (e-mail: smartin1@medicine.bsd.uchicago.edu).

\section{Compliance with Ethical Standards:}

Conflict of Interest: The authors declare that they do not have a conflict of interest.

\section{REFERENCES}

1. National Resident Matching Program, Data Release and Research Committee: Results of the 2015 NRMP Applicant Survey by Preferred Specialty and Applicant Type. Washington, DC: National Residency Matching Program; 2015.

2. Falcone JL. Home-field advantage: the role of selection bias in the general surgery national residency matching program. J Surg Educ. 2013;70(4):461-465.

3. Silvestre J, Lin IC, Serletti JM, Chang B. Geographic Trends in the Plastic Surgery Match. J Surg Educ. 2016;73(2):270-274.

4. Johnson AP, Svider PF, Folbe AJ, et al. An evaluation of geographic trends in the otolaryngology residency match: home is where the heart is. JAMA Otolaryngol Head Neck Surg. 2015;141(5):424-428.

5. Pereira AG, Chelminski PR, Chheda SG, et al. Application Inflation for Internal Medicine Applicants in the Match: Drivers, Consequences, and Potential Solutions. Am J Med. 2016;129(8):885-891. 